\title{
The Reproduction and Circulation of Knowledge in Islamic Civilization: An Example from Fifteenth-Century Samarqand
}

Mehmet Arzkan**

\begin{abstract}
History begins with writing," because writing is the most important and reliable tool for transmitting knowledge to future generations. It has made use of various materials for this very purpose for centuries and one of these materials is paper. The transmission of paper to the Islamic world and its subsequent vast production allowed books to become widespread and made paper the most important medium for written transmissions. We do not have a great deal of first-hand information on how books were prepared other than the compilation process which we know due to the presence of some compilers' anecdotes regarding the characteristics of the compilation which is an aspect of its meaning. However, producing a book as a commodity is just as important as compilation in the sense of reproduction and circulation of knowledge. This article introduces the accounts of 'Abd al-Razzāq al-Tirmidhì, a copyist who was fully engaged in the copying stage of book production. The intellectual and scientific life of the period will be discussed based on his list, which was recorded on the last page of a copy of the Mathnawi written in Samarqand in 1417. Several questions will also be raised for future studies.
\end{abstract}

Keywords: 'Abd al-Razzāq al-Tirmidhī, manuscript, copy, copyist, Samarqand, Ulugh Beg.

\footnotetext{
* I would like to express my thanks to İhsan Fazloğlu for encouraging this research and for reading the paper. I also wish to thank Abdülsait Aykut and Abdullah Uğur for carefully reading the text and proposing suggestions.

** Res. Assist., Istanbul Medeniyet University, Department of History of Sciences. Correspondence: mehmet280@gmail.com
} 
In his famous work al-Mațālib al-ilāhiyya fì mawdū'āt al-ulūm al-lughawiyya, Molla Luțfí of Tokat, a remarkable scholar who lived during the reigns of Mehmed II (r. 1444-1446 and 1451-1481) and Bayezid II (r. 1481-1512), clarifies the transmission process of the verbal expression to the written text with the help of two major concepts, namely, mukhātab and ghäib, following the mainstream view in Islamic intellectual history. While verbal expression is eligible for mukhätab (present), written text is more suitable for ghayr-i mahsūs (non-sensible), ghäib (non-present), mukhayyal (imaginary), or ma'qūl (intelligible). Ghāib is also divided into the horizontal and vertical planes: the people with whom one may share the same time and place and those with whom one do not (i.e., the future generations), respectively. In this frame, the act of writing seeks to transmit knowledge and thought to both ghäibs. ${ }^{1}$ By relating the text and its structures to the theory that he sets up for the discipline of wad', Molla Luṭfí evaluates all linguistic branches and literary arts. As a result, all of the procedures formed around the act of writing soon come to rely on the request of notification (iläm) and information (isti'lām).

In terms of the history of sciences, -either in Islamic civilization or humanity in general-, this frame of Molla Luṭî can be considered the fundamental reason for creating a book (i.e. the written text), that means recording of knowledge for the ghāib (non-present) and making it an object of both horizontal and vertical transmission. As a result, through the process of embodying the written text in Islamic civilization, the emergence of paper and other book-related crafts made knowledge an indispensable value in both material and spiritual terms. In other words, the introduction of paper and the emergence of the book and crafts related to the written text endowed the act of writing and its components with economic and financial value. Due to the subsequent transmission and circulation procedures, knowledge production became a scientific and literary activity in addition to its political, governmental, economic, technical, and esthetic aspects. As these points are very serious in terms of Islamic civilization, scholarly analyses of copying and transmitting books should be regarded as crucial to understanding the history of philosophy and sciences in the Islamic world.

1 Tokatlı Hasanoğlu Lütfullah (Molla Lütfi), Dil Bilimlerin Sinıflandırılması (el-Metâlib el-ilâhiyye fî mevzûât el-ulûm el-luğaviyye), critical edition and research: Şükran Fazlıoğlu (İstanbul: Kitabevi, 2012), 66-67 (in Arabic part: 214-215). 
The book, as a representation of writing for this manuscript-based civilization, identifies the production and circulation of knowledge. Therefore, researching the continuity and prevalence of knowledge in the hand-written culture of Islamic civilization is a very important undertaking. Some special questions may arise in our general problematic: Who produced the books? How and why did they produce them? How did they direct the production process? What was the social status of those involved in this process? How did they create a book in line with the existing individual, institutional, religious, or political procedures? Then, how did it survive by reading and being transformed into financial and moral values? How did the methods of production and reading determine a book's form? What did "book" mean in the oral culture of that time? What were the relationships of booksellers, authors, copyists, owners, patrons, illuminators, and bookbinders to the books, given that they were the ones who formed its internal and external parts? Especially, how did readers accept and adopt a book?

Beside the problems on the production and writing process, those following questions are also important: What did "book reading" mean at different times and in the various regions of the Islamic world? What about the values of learning and teaching "the process of reading" and the positions of institutions in terms of reading and writing a special book? What kinds of relationships existed between producing and consuming a book? Were there specific places and times for reading? Did individual or collective reading styles/manners develop? What about the roles of libraries in this process and the value of records such as recitation (al-qirāa), audition note $\left(\operatorname{sim} \bar{a}^{\prime}\right)$, and collation (al-muqābala) in terms of a reading culture?

The number of questions derived from the works on the history of writing, books, reading, and other related issues can surely be increased. ${ }^{2}$ However, we

2 Various contemporary works pay attention to the writing, books, reading culture, and circulation of knowledge in a specific city, region, country, or era, or by a person. Some important works are George Makdisi, The Rise of Colleges: Institutions of Learning in Islam and the West (Edinburgh: Edinburgh University, 1981); Jonathan P. Berkey, The Transmission of Knowledge in Medieval Cairo: A Social History of Islamic Education (Princeton: Princeton University Press, 1992); Gregor Schoeler, The Oral and the Written in Early Islam, trans. Uwe Vagelpohl, ed. James E. Montgomery (London: Routledge, 2010); Gregor Schoeler, The Genesis of Literature in Islam from the Aural to the Read, trans. Shawkat M. Toorawa (Einburgh: Edinburgh University Press, 2011); Johannes Pedersen, The Arabic Book, ed. Robert Hillenbrand, trans. Geoffrey French (Princeton: Princeton University, 1984); Carl F. Petry, The Civilian Elite of Cairo in the Later Middle Ages (Princeton: Princeton University Press, 1981); Bayard Dodge, Muslim Education in Medieval Times (Washington, DC: The Middle East Institute, 1962); Konrad Hirschler, The Written Word in the Medieval Arabic Lands: A Social and Cultural History of Reading Practices (Edinburgh: Edinburgh University Press, 2012); and Andreas Görke and Konrad Hirschler, ed., Manuscripts Notes as Documentary Sources (Beirut: Orient-Institut Beirut; Würzburg: Ergon in Kommission, 2011). Besides İsmail Erünsal's work on the topic, see a recently published work directly based upon the anlaysis of manuscripts: Berat Açıl, ed., Osmanlı Kitap Kültürü: Carullah Efendi Kütüphanesi ve Derkenar Notları, (Ankara: İlem Kitaplığı, 2014). 
would like to answer such questions by presenting a striking example of a copying process that we found recently. As far as we know, these kinds of examples are very scarce in the history of Islamic civilization. ${ }^{3}$

\section{I. 'Abd al-Razzāq al-Tirmidhī and His Copying Activities}

Nizām al-Dīn 'Abd al-Razzāq al-Ḥāíz ibn al-Imām Muhammad ibn Manșūr alKhațîb al-Tirmidhi ${ }^{4}$ lists all of the books that he copied throughout his life, at the end of a manuscript of Mawlānā Jalāl al-Dīn al-Rūmī's Mathnawì, which he copied on 6 Jumādā II 820/21 July 1417 at Samarqand for a statesman whom we know nothing but his name: Sayyid Amīr Dāwūd ibn al-Amīr al-Mu'az̧zam Sayyid Amīr Muhammad al-Samarqandī al-Darghamīi ${ }^{5}$. According to the information provided at the beginning of the list, the copyist was sixty-six years old when he produced it. He started his career very early and by the age of seven had become a hâfiz (someone who has memorized the Qur'an). He studied some books on Arabic language, literature, and logic; learned calligraphy; and clearly stood out among his peers. Our copyist finished his statements by stressing that he had done this type of work for fifty-eight years, thereby indicating that he had been doing since he was just eight years old. He ended his list by asking God to help him to maintain the same activities for the rest of his life.

Before analyzing Niẓām al-Dīn al-Tirmidhī’s list, we should emphasize the following point: Afore writing this list, al-Tirmidhī copied al-Bayḍāwīs Minhāj and Tavāli‘ on 9 Ramaḍān 803/23 April $1401^{6}$. Because he was still copying in the later years of his life, his prayer must have been answered: Four years after writing the list, in Rajab 824/July 1421, he copied the section of Asmä' from Zamakhsharì's Muqaddima, which deals with Arabic nouns ${ }^{7}$. Further research will help us determine if other manuscripts were recorded in al-Tirmidhì's list.

As his nisba (i.e., an adjective designating one's place of origin) indicates, Nizām al-Dìn must have been from Tirmidh. The reference to his father and grandfather in his laqab (i.e., epithet), such as imām and khațīb, shows that he was born into

Mustaqīmzāda Suleymān Sa'd al-Dīn Efendi (d. 1202/1788) gives the names and numbers of books that a scriber copied in his work Tuhfa-i Khațțāțin (Süleymaniye Library, Murad Molla 1448, pp. 28 in the margin). The manuscript is numbered in pages instead of folios.

4 Appendix 3 (Süleymaniye Library, Fatih 2810, 299a).

5 Appendix 4 (Süleymaniye Library, Fatih 2810, 1a-"frontispiece").

6 Qum-Mar'ashī Library, Ms 509.

7 Süleymaniye Library, Fatih 5274. 
a family of scholars during 754/1353-54, taking the date of the list into consideration. Therefore, he must have experienced his best years during the Timurid era, which Timur had initiated in 771/1370. At this copyist's time, the Timurid Empire was being governed by Amīr Timur's son Shāhrukh (820/1417), who had conquered Samarqand in 811/1409. During the year in which al-Tirmidhi wrote his list, Ulugh Beg, the grandson of Timur (and son of Shāhrukh), established the Madrasa of Ulugh Beg. In addition, the construction of Samarqand Observatory began in $827 / 1424^{8}$. In light of this data, al-Tirmidhī's copying activity took place primarily during the Timurid era around Turkistan and Iran, even though he had started a little bit earlier. Perhaps he undertook this activity to meet the needs of scholars and pupils at the madrasas located around Herat and Samarqand.

\section{A Short Evaluation of al-Tirmidhī's Copying Activities}

Al-Tirmidhī's list shows us how much one copyist could do in terms of transmitting knowledge and its influence. It also indicates this activity's economic value, as well as the density and depth of scientific activities in that region. According to the law of supply and demand, the production and acceptance of the books must fulfill a gap in the scientific environment as well as in the market. Of course, the techniques of calligraphy and the book's ornamentations and bindings indicate the depth of writing and reading activities, along with the background of the region in which they were produced. During fifty-eight years, al-Tirmidhī made 714 copies of sixty-eight different books mentioned in his list. We believe that these numbers provide a sufficient framework for what we have written up to now. ${ }^{9}$

In addition to these general conclusions on al-Tirmidhī's list, we also want to share some of our findings as regards the content so that scholars can evaluate the statistical data related to the branches of sciences, the number of manuscripts, and their compilation dates. They also can read and inspect this list from different perspectives.

It is noteworthy that the list contains many works from the post-Fakhr al-Din al-Rāzì (d. 606/1210) era, including thirty books written between 600/1204 and $750 / 1350$, which were copied 217 times. Another noticeable point is that eleven books written between 700/1300 - 750/1350 were copied 109 times, perhaps

For further information, see İhsan Fazlığlu, "The Samarqand Mathematical-Astronomical School: A Basis for Ottoman Philosophy and Science", Journal for the History of Arabic Science, XIV/1, 2 (2008): 3-68. For the Samarqand Observatory, see Aydın Sayll, The Observatory in Islam, 2d ed. (Ankara: TTK, 1988), $260 \mathrm{ff}$.

9 See Table 1 and Figures 1 and 2. 
because they were compiled relatively shortly before the aforementioned period. They were also preferred probably due to the influence of Shanb-i Ghāzān and Rab'-i Rashīdī in Tabrīz. ${ }^{10}$ The list includes the common features of cultural basins in Islamic civilization along with local qualities. As an example, we can find commonly followed works such as Zamakhsharī's (d. 538/1144) Kashshāf, al-Bayḍāwī’s (d. 685/1286) Anwār and Ṭawāli‘, Shams al-Dīn al-Ișfahānī’s (d. 749/1349) Mațāli (his commentary on Tawāli'), and the commentary on Shamsiyya (on logic), all of which were circulating in various regions of the Islamic world. The list includes also some Sanskrit medical works translated into Persian.

If we examine the list closely, we can detect Hanafī fiqh works both in uṣūl and furū'. Three books on ușūl were copied 12 times, 5 books on furū were copied 28 times, and 2 books on khiläf were copied 5 times. Sufi works occupied 15 percent of the list, among them those by Farīd al-Dīn al-'Aț̣ār (d. 589/1221), al-Rūmī (d. 672/1273), Khwāja 'Abdullah Harawī (d. 481/1089) and Ghazzālī (d. 505/1111). ${ }^{11}$ Also mentioned are Taftāzānī (d. 792/1390) and al-Sayyid al-Sharīf al-Jurjānī (d. 816/1413), remarkable rivals who were that era's predominant intellectuals. We can observe that the recent (or "updated") works achieved a wide circulation and became goods of supply and demand in a very short time: Nine works and forty-eight copies were completed after $750 / 1350 .{ }^{12}$

After the Qur'ān (copied 180 times), the most copied books were those on the Arabic language and rhetoric. Al-Tirmidhī produced 264 copies of eighteen works written in different branches of linguistics. Because some of the entries were mentioned under general titles like "linguistics" and "grammar", one might think that the number would be higher. If we take into consideration that three dictionaries were copied thirteen times a significant number of copies comes up as total. It indicates the need for such books in the Persian- and Turkish-speaking lands and emphasizes the vital position of the instrumental disciplines (i.e., language textbooks) in madrasa education. No classical well-known medical books appear in the list. Only four medical works were copied eighteen times: the first was a work by Najīb al-Dīn al-Samarqandī (d. 619/1222); the other three were of Indian origin. Surprisingly, the medical books of Indian tradition (translated from Sanskrit to Persian) were copied fifteen times, whereas one medical work of Islamic culture was copied just three times. ${ }^{13}$

13 See the thirty-sixth and thirty-seventh articles in Appendix 1 and 2. 
The absence of quadrivium books of mathematics ${ }^{14}$ is also notable, for al-Tirmidhī was active in Samarqand and its surrounding areas at a time when scientific activity was reaching its peak. In fact, the key works of the mathematical sciences for the next century were produced there. Even though 53 percent of the works listed were compiled after 650/1252, ${ }^{15}$ the following works were not listed: Ṭūsīs Tahrīrāt project $^{16}$ (compiled between 644-663/1247-1265), the works of Quṭb al-Dīn Shīrāzi (d. 710/1311) or Niẓām al-Dīn Nīsābūrī (d.730/1329) on riyāệ̀yāt (mathematical sciences), the commentaries by Qādīzāda al-Rūmī (d. after 844/1440) on the $M u$ lakhkhas (compiled in 814/1412) and Ashkāl al-ta'sīs (compiled in 815/1413) which he completed at Samarqand while al-Tirmidhī was preparing his list, or the works by al-Jurjānī such as Sharḥ al-tadhkira (compiled in 811/1409). On the other hand, our copyist did mention nine copies of Hāshiya (a supercommentary on Kashshāf), a far more voluminous work by Jurjānī.

We have a few possible explanations for this phenomenon: (1) there was no strong interest on the mathematical sciences in his region, especially in the late fourteenth and early fifteenth centuries. However, this opinion seems very weak because Ghiyāth al-Dīn al-Kāshī (d. 832/1429), who was in Samarqand during the same period, refers in one of his letters to the presence of sixty or seventy people engaged in those sciences ${ }^{17}$; (2) al-Tirmidhīs education and experience had not prepared him to comprehend mathematical texts with their notations and drawings on the mathematical sciences. ${ }^{18}$ This seems more plausible, for geometric and astronomical drawings were especially indispensable for gaining the most benefit from such books; and (3) some special copyists already dominated (or maybe monopolized) copying books dealing with certain branches of the sciences. ${ }^{19}$

15 See Figure 3.

16 For the books and their compilation dates in the Tahrīrāt Project, see Nasîrüddîn Tûsî, Tahrîru Usûli'lHendese ve'l-Hisâb: Euklides'in Elemanlar Kitabının Tahrîri, prepared by İhsan Fazlıŏlu (İstanbul: Türkiye Yazma Eserler Kurumu Başkanlığ1, 2012), 38-39.

17 Aydın Sayılı, Uluğ Bey ve Semerkanddaki İlim Faaliyeti Hakkında Gıyasüddin-i Kâşînin mektubu = Ghiyâth al Dîn al Kâshî̀s letter on Ulugh Bey and the Scientific Activity in Samarqand (Ankara: Türk Tarih Kurumu Basımevi, 1960), 68, 86.

18 This opinion is supported by the fact that al-Tirmidhī does not refer to any mathematical sciences at the beginning of the list, where he talks about his education in detail. (See Appendix 1 and 2).

19 Here is a nice example of sixteenth-century copy activity: Mehmed Efendi (d. 1020/1611) copied Qinalizāda 'Alī Efendī's (d. 979/1572) Akhlāq-i 'Alā̄ì fourty times and was nicknamed "Akhlāqī" (one who is related to the book of Akhlāq). See Şevket Rado, Türk Hattatları: XV. Yüzyıldan Günümüze Kadar Gelmiş Ünlü Hattatların Hayatları ve Yazılarından Örnekler (İstanbul: Yayın-Matbaacılık Ticaret Limited Şirketi, nd.), 85. Mehmed Efendi's fourtieth (and the last) copy of this book is dated 14 Ramadan 1007/10 April 1599. It is now in Esad Efendi collection in the Süleymaniye Library, number 1804. 
In this study, we tried to analyze al-Tirmidhī's list as a remarkable booklet in terms of copying texts as well as of producing books, reading, and writing. Undoubtedly, the reproduction and circulation of knowledge are important for the history of sciences. Copying as an "institution", the copyists, and the works they copied indicate that knowledge has material and financial value, as well as spiritual tenets. In addition to the general principles mentioned above, the cultural environment that created al-Tirmidhï's list and similar ones might be considered a vital sign of the strength of scientific activities in a given region.

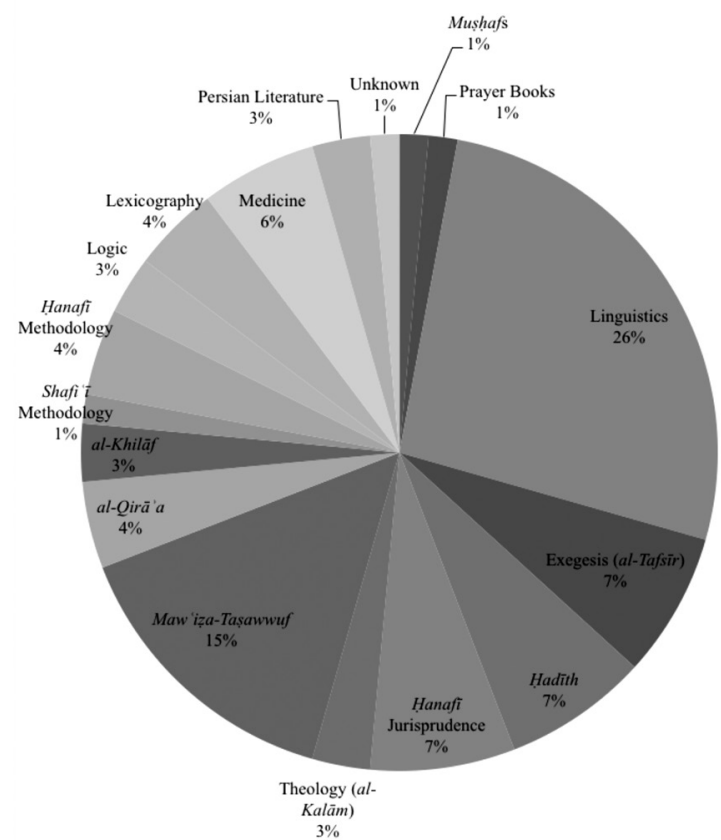

Figure 1. The distribution of sciences, considering number of works (over sixty-eight works) 


\section{Table 1. Table of Sciences}

This table shows the number of works and copies produced in the various scientific disciplines

\begin{tabular}{|c|c|c|}
\hline Science & Number of Works & Number of Copies \\
\hline Mușhafs & 1 & 180 \\
\hline Prayer books & 1 & 90 \\
\hline Linguistics & 18 & 264 \\
\hline Exegesis (al-Tafsīr) & 5 & 26 \\
\hline Hadith & 5 & 15 \\
\hline Hanafï Jurisprudence & 5 & 28 \\
\hline Theology (al-Kalām) & 2 & 2 \\
\hline Mawiza-Tașawwuf & 10 & 22 \\
\hline Al-Qirā'a & 3 & 19 \\
\hline Al-Khilāf & 2 & 5 \\
\hline Shafì Methodology & 1 & 2 \\
\hline Hanafi Methodology & 3 & 12 \\
\hline Logic & 2 & 8 \\
\hline Lexicography & 3 & 13 \\
\hline Medicine & 4 & 18 \\
\hline Persian Literature & 2 & 9 \\
\hline Unknown & 1 & 1 \\
\hline Total & 68 & 714 \\
\hline
\end{tabular}




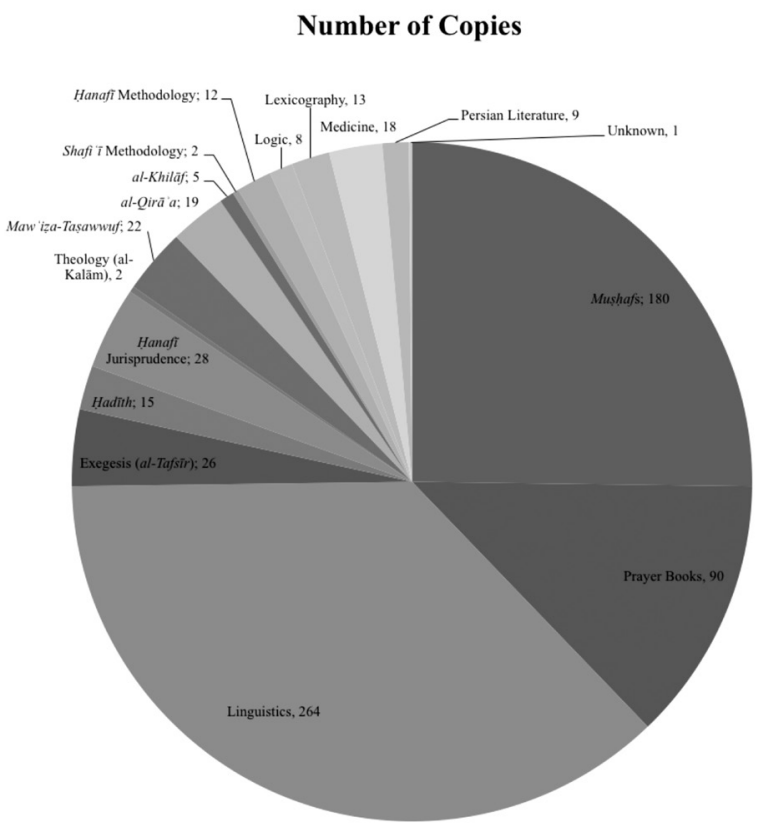

Figure 2. The number of copies in the various scientific disciplines (714 copies)

\section{Compilation Dates}

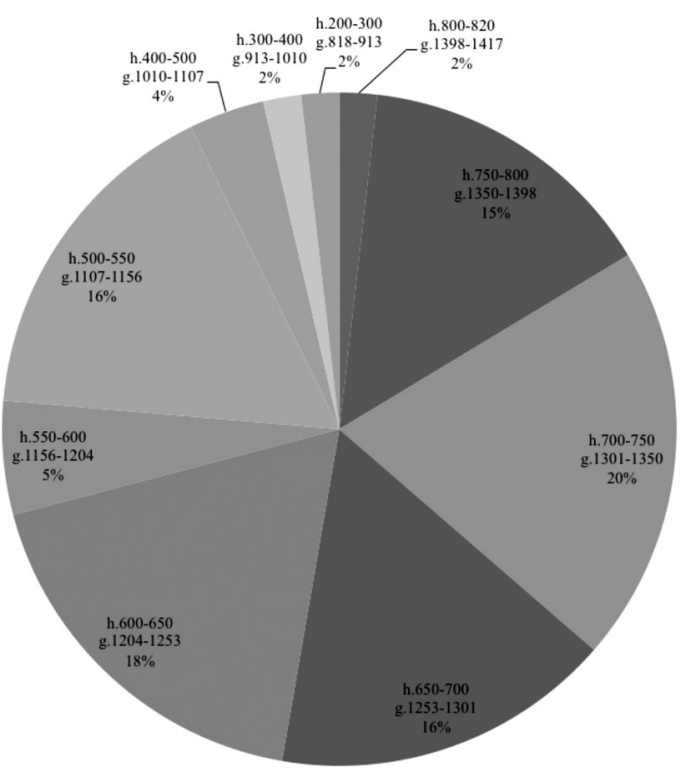

Figure 3. The percentage of works according to their compilation dates (sixty-eight works): $\mathrm{h}$ = Hijrī; $g$ = Gregorian 
Table 2. Compilation date ranges

Figure 3 provides the compilation date percentages of the works. Here, Table 2 shows the number of the works and copies, along with the works with unknown compilation dates:

\begin{tabular}{lll}
\hline Compilation Dates (Approximately) & Number of Works & Number of Copies \\
\hline $800-820 / 1398-1417$ & 1 & 9 \\
\hline $750-800 / 1350-1398$ & 8 & 39 \\
\hline $700-750 / 1301-1350$ & 11 & 109 \\
\hline $650-700 / 1253-1301$ & 9 & 45 \\
\hline $600-650 / 1204-1253$ & 10 & 63 \\
\hline $550-600 / 1156-1204$ & 3 & 19 \\
\hline $500-550 / 1107-1156$ & 9 & 41 \\
\hline $400-500 / 1010-1107$ & 2 & 22 \\
\hline $300-400 / 913-1010$ & 1 & 2 \\
\hline $200-300 / 818-913$ & 1 & 2 \\
\hline Unknown date & 12 & 183 \\
\hline Mușhaf & 1 & 180 \\
\hline Total & $\mathbf{6 8}$ & $\mathbf{7 1 4}$ \\
\hline
\end{tabular}

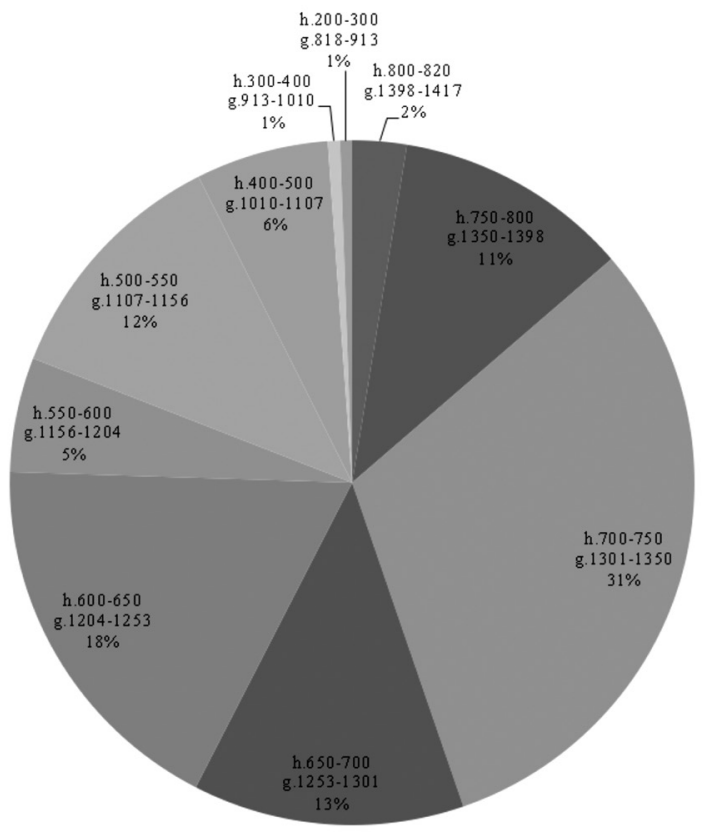

Figure 4. Distribution of copies according to the compilation date ranges (714 copies): $\mathrm{h}$ = Hijrī; $g$ = Gregorian 


\section{Bibliography}

Benli, Mehmet Sami, “el-Mufassal”, Türkiye Diyanet Vakfı İslâm Ansiklopedisi (DİA), v. XXX, 368-369.

Çağrıcı, Mustafa, "İhyâü Ulûmi’d-dîn”, DİA, v. XXII, 10-13.

Çollak, Fatih, “eş-Şâtıbiyye”, DİA, v. XXVIII, 377-379.

Fazlığlu, İhsan, “Osmanlı Felsefe-Biliminin Arkaplanı: Semerkand Matematik-Astronomi Okulu”, Derin Yapı İslâm-Türk Felsefe-Bilim Tarihi’nin Kavram Çerçevesi, 2d. ed. (İstanbul: Papersense Yayınları, 2015), 15-65.

"The Samarqand Mathematical-Astronomical School: A Basis for Ottoman Philosophy and Science", Journal for the History of Arabic Science, XIV/1, 2 (2008): 3-68.

al-Ḥabashī, 'Abd Allah Muḥammad, Jāmi' al-shurūḥ wa-al-ḥawāshī, Abu Dhabi: al-Majma' al-Thaqāfī, 2004.

Hatiboğlu, İbrahim, "Mesâbîhu's-sünne”, DİA, v. XXIX, 258-260.

Kallek, Cengiz, "el-Hidâye”, Dİ, v. XVII, 471-473.

Kandemir, M. Yaşar, “el-Câmiu's-sahîh”, DİA, v. VII, 114-123.

Qinalizāda 'Alī Efendī, Akhlāq-i 'Alā'̄, Süleymaniye Library, Esad Efendi, 1804.

Kātib Chalabī, Hajjī Khalīfa Muṣtafā b. 'Abd Allāh, Kashf al-ẓunūn 'an asāmī al-kutub wa al-funūn, corr. M. Şerefettin Yaltkaya (Ankara: Milli Eğitim Bakanlığı, 1941).

Kılıç, Hulusi "el-Kâfiye”, DİA, v. XXIV, 153-154.

“Tâcü'l-luga”, DİA, v. XXXIX, 356-357.

Koca, Ferhat “el-Manzûmetü'n-nesefiyye”, Dİ, v. XXVIII, 34-35.

Meulenbeld, G. Jan, A History of Indian Medical Literature, V. IA (Groningen: Forsten, 1999).

Müstakîmzâde Süleyman Sa'deddin Efendi, Tuhfe-i Hattâtîn, Süleymaniye Library, Murad Molla, 1448.

Özek, Ali, “el-Keşşâf”, DİA, v. XXV, 329-330

Rado, Şevket, Türk Hattatları: XV. yüzyıldan günümüze kadar gelmiş ünlü hattatların hayatları ve yazılarından örnekler (İstanbul: Yayın-Matbaacılık Ticaret Limited Şirketi, t.y.).

Sayılı, Aydın, Uluğ Bey ve Semerkanddeki İlim Faaliyeti Hakkında Glyasüddin-i Kâşînin Mektubu (Ghiyâth al Din al Kâshî̀ Letter on Ulugh Bey and the Scientific Activity in Samarqand (Ankara: Türk Tarih Kurumu Basımevi, 1960).

The Observatory in Islam, 2. Baskı (Ankara: TTK, 1988).

Şahinoğlu, M. Nazif, “Attâr, Ferîdüddîn”, DİA, v. IV, 95-98.

Tokatlı Hasanoğlu Lütfullah (Molla Lütfi), Dil Bilimlerin Sinıflandırılması (el-Metâlib el-ilâhiyye fì mevzûât elulûm el-luğaviyye), Eleştirel metin ve inceleme: Şükran Fazlığlu (İstanbul: Kitabevi, 2012).

Tûsî, Nasîrüddîn Tahrîru Usûli'l-Hendese ve'l-Hisâb: Euklides'in Elemanlar Kitabının Tahrîri (inceleme-tıpkıbasım), prepared by İhsan Fazlığlu (İstanbul: Türkiye Yazma Eserler Kurumu Başkanlığı, 2012).

Yazıcı, Tahsin , "Hâfız-1 Şîrâzî", DİA, v. XV, 103-106.

Yetik, Erhan “Menâzilü's-sâirîn”, DİA, v. XXIX, 122-123. 


\section{Appendix 1. The list of books copied by al-Tirmidhi (edition)}

Süleymaniye Library, Fatih 2810, f. 299b

$$
\text { بسم الله الرحمن الرحيم }
$$

الحمد لله ربّ العالمين والعاقبة للمتقين ولا عدو ان إلا على الظالمين والصلاة على رسوله محمد وآله

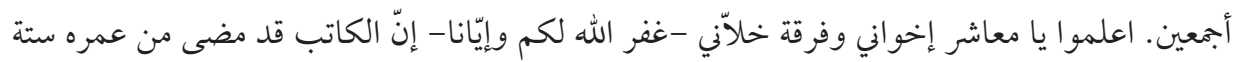

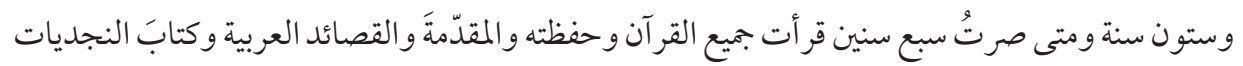

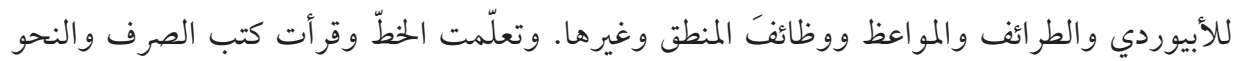

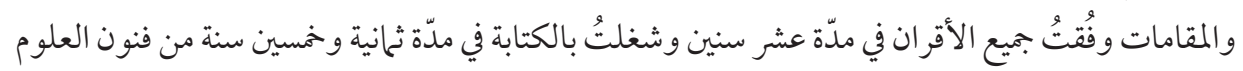

$$
\begin{aligned}
& \text { و أفصّلها على هذا التفصيل: } \\
& \text { كُتب من المصاحف: مأية وثمانون حفظًا. }
\end{aligned}
$$

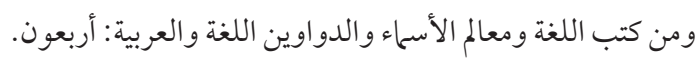

$$
\begin{aligned}
& \text { ومن الكثّاف: اثنان. } \\
& \text { ومن التفسير شرح البيضاوي: اثنان. }
\end{aligned}
$$

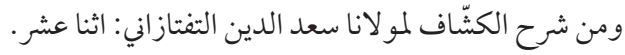

$$
\begin{aligned}
& \text { ومن صحيح البخاري في علم الحديث: اثنان. } \\
& \text { ومن المصابيح: اثنان. } \\
& \text { ومن مشارق الأنوار في الأحاديث: سبع. ومن المبان } \\
& \text { ومن كيمياء السعادة: اثنان. } \\
& \text { ومن كتب القر اءة والشاطبي وشرحه: تسعة عشر . } \\
& \text { ومن شرح الكشّاف للسيد الشريف: تسع. } \\
& \text { ومن شرح الكشّاف لمو لانا علي البهلوان: أحد. } \\
& \text { ومن اليواقيت في الأحاديث: اثنان. } \\
& \text { ومن مرصاد العباد: ثلاث. } \\
& \text { ومن إحياء العلوم: أحد. } \\
& \text { ومن المنظومة: أربع. } \\
& \text { ومن المختلف في شرحها: أحد. } \\
& \text { ومن المنهاج: اثنان. }
\end{aligned}
$$

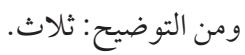

$$
\begin{aligned}
& \text { ومن الأدعية المكمّلة: تسعون. } \\
& \text { ومن خلاصة الفتاوى: ثلاث. } \\
& \text { ومن فصول العمادي: اثنان. }
\end{aligned}
$$




$$
\begin{aligned}
& \text { ومن التحقيق لمو لانا عبد العزيز البخاري في أصول الفقه: سبع. } \\
& \text { ومن المفصّل : خمس عشرة. } \\
& \text { ومن الكافية: عشرون. } \\
& \text { ومن اللبّ و اللباب: سبع عشرة. } \\
& \text { ومن شرح اللباب المعروف بالفالي: ثلاثون. }
\end{aligned}
$$

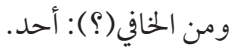

$$
\begin{aligned}
& \text { و ومن المنطق شرح الشمسية و القسطاس: ثلثانية. }
\end{aligned}
$$

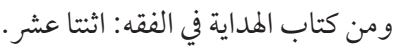

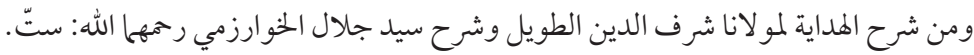

$$
\begin{aligned}
& \text { ومن شرح الوقاية في الفقه: سبع. } \\
& \text { ومن مقامات الحريري: ثلاث. } \\
& \text { ومن صحاح اللغة: اثنان. } \\
& \text { و من الصراح؛ مختصره: مثله. }
\end{aligned}
$$

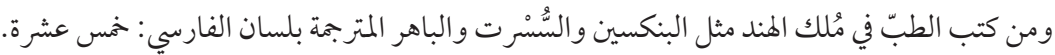

$$
\begin{aligned}
& \text { ومن الأسباب و والعلامات في الطبّ: ثلاث. } \\
& \text { ومن كتب الصرف: اثنان و أربعون. } \\
& \text { ومن المصباح والجمل : خمس وثلاثون. } \\
& \text { ومن علم العروض: ثمانية. } \\
& \text { ومن المفتاح: أحد عشر مع أقسامها. } \\
& \text { ومن شروح القصائد: ست عشرة. }
\end{aligned}
$$

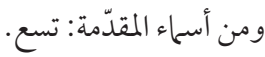

$$
\begin{aligned}
& \text { ومن منازل السائرين في علم التصوف: خمس. } \\
& \text { ومن المطوّل والمختصر : إحدى عشرة. }
\end{aligned}
$$

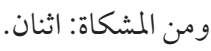

$$
\begin{aligned}
& \text { ومن الضوء: خمس. } \\
& \text { ومن شرح الشافية: اثنان المعروف بالجاربردي. } \\
& \text { ومن المتوسّط: ثمانية. } \\
& \text { ومن شرح الرضي: أحد. } \\
& \text { ومن الطوالع في علم الكلام ومن المطالع: اثنان. } \\
& \text { ومن دواوين الفارسية مثل ديو ان حافظ الشيرازي ومن ديو ان من مولان لانا جلال الدين الرومي: تسع. }
\end{aligned}
$$

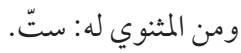

$$
\begin{aligned}
& \text { ومن عطّاريات مثل إلهّي نامه وأسرار نامه ومصيبت نامه وأشتر نامه ومنطق الطير : خمس نقس } \\
& \text { اللهم وفّق لنا في بقية العمر مثلها. }
\end{aligned}
$$




\section{Appendix 2. The list of books copied by al-Tirmidhi (translation)}

In the name of Allah, the Most Gracious, the Most Merciful

Praise be to Allah, the Cherisher and Sustainer of the worlds. The end is (best) for the righteous. Let there be no hostility, except to those who practise oppression. Blessings upon His messenger Muhammad and his family.

O brothers and friends! May God have mercy upon you and me! You must know that this copyist has spent sixty-six years of his life. At the age of seven I read and memorized the whole Qứa an. I also read and memorized al-Muqaddima ${ }^{20}$, Arabic poems $^{21}$ (al-qasāid al-arabiyya), al-Abīwardī's Kitāb al-Najdiyyāt ${ }^{22}$, selected texts, preaching works (al-mawā'iz), Wazáif al-manțiq ${ }^{23}$, and etc. I learned Arabic calligraphy (al-khatț) and read grammar books (morphology and syntax) and al-Ma$q \bar{a} m \bar{a} t^{24}$. I overcame all my peers in ten years. I have been busy with scribing [texts belonging to] different branches of sciences (funūn al-üūum) for fifty-eight years.

Here the details:

[1] Books of al-Mașāhifif ${ }^{25}$ : hundred and eighty copies by heart.

[2] Of linguistics and ma'älim al-asmä' and collected booklets on language (dawāwīn al-lugha), [especially] Arabic: fourty copies.

[3] Of al-Kashshā ${ }^{26}$ : two copies

[4] Of Sharh al-Baydāwwīi ${ }^{27}$ on exegesis (al-tafsïr): two copies

Many well-known works bear this title. As far as I understand, the book mentioned here is an introe duction to Arabic. Among those that were compiled on linguistics before the list are (i) Zamakhshari's (d. 538/1144) Muqaddima al-Adab (Hajjī Khalīfa Muștafā b.'Abd Allāh Kātib Chalabī, Kashf al-zunūn 'an asāmī al-kutub wa al-funūn, corr. M. Şerefettin Yaltkaya (Ankara: Milli Eğitim Bakanlığı, 1941) [hereinafter Kashf], 1798) (ii) Abū 'Abd Allāh Muḥammad b. Muhammad b. Dāwūd al-Sanhājī, known as Ibn Ājurrūm's (d. 723/1323) Muqaddima (Kashf, 1796) and (iii) Abū Mūsā 'Īsā b. 'Abd al-'Azīz b. Yalalbakht al-Jazūlì's (d. 607/1210) al-Muqaddima al-Jazūliyya (Kashf, 1800).

21 It may mean heuristic, didactic poems on Arabic grammar.

22 Abū al-Muẓaffar Muhammad b. Aḥmad al-Umawī al-Mu'āwī al-Abīwardī's (d. 507/1113) Dīvān consist of three chapters: 'Irāqiyyāt, Najdiyyāt, and Wajdiyyāt. Kātib Chalabī mentions another work of Abīwardī on genealogy ('ilm al-nasab): Najdiyyāt (Kashf, 1930).

23 Shams al-Dīn Muhammad b. Mūsā al-Maghribīs (d. 683/1284) work on logic (Kashf, 2015).

24 Most probably al-Harīrī's al-Maqāmāt (see below).

25 Al-Mașāhif, the plural form of al-Mușhaf: “copies of the Qư'an”.

26 Abū al-Qāsim Maḥmūd b. 'Umar b. Muhammad al-Khwārizmī al-Zamakhsharī’s (d. 538/1144) exegesis on the Qur'an, al-Kashshāf 'an haqā’iq ghawāmiḍ al-tanzīl wa 'uyūn al-aqāwīl fì wujūh al-ta'wīl (Ali Özek, "el-Keşşâf”, Türkiye Diyanet Vakfi İslâm Ansiklopedisi (DİA), v. XXV, 329-330).

The title of Sharh al-Baydāwī means that this work is a commentary on Nāșir al-Dīn Abū Sa'īd 'Abd Allāh b. 'Umar al-Bayḍāwī's (d. 685/1286) famous exegesis Anwār al-tanzīl wa asrār al-ta'wīl. However, the compiler's name is not given. The well-known commentaries written before the list are as follows: 
[5] Of Sharḥ al-Kashshā ${ }^{28}$ of Mawlānā Sa'd al-Dīn al-Taftāzānī: twelve copies

[6] Of Șaḥịh al-Bukhārī'29 on 'ilm al-ḥadīth: two copies

[7] Of al-Mașābīh ${ }^{30}$ : two copies

[8] Of Mashāriq al-Anwār ${ }^{31}$ on al-aḥādìth: seven copies

[9] Of Kìmyā' al-Sa'āda ${ }^{32}$ : two copies

[10] Of books of al-qirā'a (science of reciting the Qur'an) and al-Shāțibi ${ }^{33}$ and its Sharh ${ }^{34}$ : nineteen copies

[11] Of Sharh al-Kashshā $f^{35}$ of al-Sayyid al-Sharîf: nine copies

[12] Of Sharḥ al-Kashshā ${ }^{36}$ of Mawlānā 'Alī al-Bahlawān: one copy

[13] Of al-Yawāqìt fì al-ahāadith ${ }^{37}$ : two copies

(i) Abū Bakr b. Ahmad Ibn al-Ṣā’igh al-Hanbalī’s (d. 714/1314) al-Husām al-māḍ̂̀ fì ìdāh gharīb al-qāḍ̂ (Kashf, 190); (ii) Abū Muḥammad Jamāl al-Dīn 'Abd al-Rahīm b. al-Ḥasan b. 'Alī al-Umawī al-Isnawī's (d. 772/1370) Sharh Anwār al-tanzìl; (iii) Abū 'Abd Allāh Shams al-Dīn Muhammad b. Yūsuf b. 'Alī al-Kirmānī’s (d. 786/1384) super-commentary Hāshiya 'alā Anwār al-tanzīl (Kashf, 189). Given its reputation, the most probable one among these works is Isnawi's work.

Sa'd al-Dīn Mas'ūd b. Fakhr al-Dīn 'Umar al-Harawī al-Khurasānī al-Taftāzānī’s (d. 792/1390) supercommentary on al-Kashshäf of Zamakhsharī, which is known as Hāshiya 'alā al-Kashshāf and Sharḥ. al-Kashshäf (KZ, 1478).

Abū Abd Allah Muhammad b. Ismāî̀l b. Ibrāhīm al-Ju'fī al-Bukhārīs (d. 256/870) well-known collee ction, that he compiled authentic hadiths organized them according to figh subjects. Its full name is al-Jāmi al-șaḥiḥ al-musnad min ḥadìth rasūl Allah sallā Allah 'alayhi wa sallam wa sunanihì wa ayyāmih (M. Yaşar Kandemir, "el-Câmiu's-sahîh", DİA, v. VII, 114-123).

30 Abū Muḥammad Muhyi al-Sunna al-Ḥusayn b. Mas'ūd al-Farrā’ al-Baghawìss (d. 516/1122) Masābiḥ. al-Sunna on hadith. (İbrahim Hatiboğlu, "Mesâbîhu's-sünne”, DİA, v. XXIX, 258-260).

31 Even though there are two well-known hadith works with this title, the most famous one is Abu alFaḍāil Raḍi al-Dīn Ḥasan b. Muhammad al-Sāghānī’s (d. 650/1252) Mashāriq al-anwār al-nabawiyya min șihāh al-akhbār al-Mușțafawiyya (İbrahim Hatiboğlu, "Meşâriku'l-envâri'n-nebeviyye", DİA, v. XXIX, 361-362).

32 Hujjat al-Islām Abū Hāmid Muhammad b. Muhammad al-Ghazzālī al-Ṭūsī’s (d. 505/1111) Persian work as a summary of Ihyä' 'ulūm al-dīn

33 Abū Muhammad Qāsim b. Fīrruh al-Shațibī's work in verse on qirāa. Even though the book is titled Hirz al-amānī wa wajh al-tahānī, it became famous under the name al-Shațibiyya, with reference to the author. (Fatih Çollak, "eş-Şâtıbiyye", DİA, v. XXVIII, 377-379).

34 The most well-known commentary on Hịrz al-amānī is Burhān al-Dīn Abū Ishāa Ibrāhīm b. 'Umar alJa‘barī's (d. 732/1332) commentary: Kanz al-ma'ānī. For Hịrz al-amānī and commentaries, see Kashf, 646-649.

35 Abū al-Hasan 'Alī b. Muhammad b. 'Alī al-Sayyid al-Sharīf al-Jurjānī's (d. 816/1413) super-commenn tary on al-Kashshāf of al-Zamakhsharī. Al-Jurjānī's work is known as Hashiya 'alā al-Kashshāf and Sharh al-Kashshāf (Kashf, 1479).

36 There is no information on the dates of birth and death of al-Bahlawān. who authored a super-comm mentary on al-Kashshāf. Since he uses the term "rahimahū Allāh" for Quṭb al-Dīn al-Rāzì (d. 766/1365), it is understood that he was alive after Qutb al-Dīn's death. See 'Abd Allah Muhammad al-Habashī, Jāmi' al-shurūḥ wa-al-ḥawāshī (Abu Dhabi: al-Majma' al-Thaqāfī, 2004, III, 1464).

37 I could not find any information on this book. 
[14] Of Mirșād al-‘ibād ${ }^{38}$ : three copies

[15] Of Ihyā al-'ulūm ${ }^{39}$ : one copy

[16] Of al-Manzūma ${ }^{40}$ : four copies

[17] Of its commentary, al-Mukhtalif ${ }^{41}$ : one copy

[18] Of al-Minhāj ${ }^{42}$ : two copies

[19] Of al-Taw dì $h^{43}$ : three copies

[20] Of al-Ad'iya al-mukammala ${ }^{44}$ : ninety copies

[21] Of Khūlāṣa al-fatāwa $\bar{a}^{45}$ : three copies

[22] Of Fuṣūl al-'imādī ${ }^{46}$ : two copies

[23] Of al-Taḥqīqu of Mawlānā 'Abd al-'Azīz al-Bukhārī on uṣūl al-fiqh: seven copies [24] Of al-Mufașșal ${ }^{48}$ : fifteen copies

Abū Bakr Najm al-Dīn-e Dāya 'Abd Allāh b. Muhammad al-Asadī al-Rāzī’s (d. 654/1256) Persian-language book on tașawwuf. The original title of the book is Mirșäd al-íbäd min al-mabda' ilä al-ma 'âd (Kashf, 1655).

39 Al-Ghazzālì's well-known Ihyyâ' 'ulūm al-dīn (Mustafa Çağrıcı, "İhyâü Ulûmi'd-dîn”, DİA, v. XXII, 10-13).

40 Abū Ḥafș Najm al-Dīn 'Umar b. Muhammad al-Nasafī al-Samarqandī's (d. 537/1142) work in verse on 'ilm al-khilāf, known as al-Manzūma al-Nasafiyya, Manzūma al-Nasafi fï al-khilāf, or Manzūma fĩ al-khilāf. See Ferhat Koca, "el-Manzûmetü'n-nesefiyye”, DİA, v. XXVIII, 34-35.

41 Abū al-Fath 'Alā al-Dīn Muhammad b. 'Abd al-Hamīd al-Usmandī al-Samarqandī's (d. 552/1157[?]) commentary Mukhtalifal-riwāya on al-Manzūma al-Nasafiyya. It is also known as Haṣr al-masā'il or Qașr al-Dalā'il or 'Awn al-Dirāya.

42 Many works have this title. A miscellaneous (majmū'a) in Qum-Mar'ashī library (Ms 509) copied by alTirmidhī on 9 Ramaḍān 803/23 April 1401 includes Qāḍī Bayḍāwī’s Minhāj al-wușūl ilā 'il al-uṣūl. Since no other book called Minhāj is mentioned, this one is clearly Bayḍāwìs. Minhāj al-wușūl ilā 'il al-uṣūl deals with Shafi'ì jurisprudential methodology (ușūl al-fiqh).

43 The most famous work with this title is Șadr al-Sharī'a al-Thānī 'Ubayd Allāh b. Mas'ūd al-Mahbūbī alBukhārī's (d. 747/1346) self-commentary: al-Tawdịh fi hall ghawāmid al-Tanqīh on Tanqīh al-ușūl.

44 In my research, I did not come across any book named al-Ad'iya al-mukammala. Considering its name, it is most probably a collection of prayers.

45 Iftikhār al-Dīn Ṭāhir b. Ahmmad b. 'Abd al-Rashīd al-Bukhārīs (d. 542/1147) work on Hanafī fiqh (Kashf, 718).

46 The full name of the work is Fușūl al-iḥkām fi ușūl al-aḥkām. As regards the author's name, Kashf gives two possibilities: (i) Jamāl al-Dīn b. 'Imād al-Dīn al-Ḥanafī or (ii) Abū al-Fatḥ 'Abd al-Rahịm b. Abū Bakr b. 'Abd al-Jalīl al-Marghīnānī (d. 651/1253). According to Kashf, Çivizāde Mehmed Efendī relates the work to the second author (Kashf, 1270). Kātib Chalabī also narrates that Nizām al-Dīn b. Burhān al-Dīn al-Marghīnānī, the author of Jawāhir al-Fiqh, is mentioned as "my uncle" by the author of Fuṣūl (Kashf, 615). In this case, Abū al-Fath 'Abd al-Rahīm al-Marghīnānī must be the author of this work.

47 'Alā al-Dīn 'Abd al-'Azīz b. Aḥmad b. Muhammad al-Bukhārī's (d. 730/1330) commentary on Abū 'Abd Allāh Ḥusām al-Dīn Muhammad b. Muhammad al-Akhsīkathī’s (d. 644/1246) al-Muntakhab fi uṣūl almadhhab. Al-Bukhārì's commentary al-Taḥqiq is also known as Ghayat al-tahqīq and Sharh al-Muntakhab al-ḥusāmī (Kashf, 1849).

48 Zamakhsharī's work on Arabic grammar, al-Mufașșal fi șan'at al-i'rāb, is also known as al-Mufașșal or al-Mufașșal fĩ al-naḥw. See Mehmet Sami Benli, "el-Mufassal”, DİA, v.XXX, 368-369. 
[25] Of al-Kāfiya ${ }^{49}$ : twenty copies

[26] Of al-Lubb and al-Lubāb50: seventeen copies

[27] Of Sharh al-Lubāb as known as al-Fā $\bar{l}^{51}$ : thirty copies

[28] Of al-Khāfĩ ${ }^{52}$ : one copy

[29] Of Sharh al-Shamsiyya ${ }^{53}$ and al-Qisțās ${ }^{54}$ on the logic: eight copies

[30] Of Kitāb al-Hidāya ${ }^{55}$ on al-fiqh: twelve copies

[31] Of Sharh al-Hidāya ${ }^{56}$ of Mawlānā Sharaf al-Dīn al-Ṭawīl and Sharḥ ${ }^{57}$ of

Sayyid Jalāl al-Khwārizmī (May Allah have mercy on them): six copies

[32] Of Sharh al-Wiqāya ${ }^{58}$ on al-fiqh: seven copies

[33] Of Maqāmāt al-Harīiñ̄i ${ }^{59}$ : three copies

[34] Of Șihāh al-lugha ${ }^{60}$ : two copies

[35] Of its epitome al-Ṣurāh ${ }^{61}$ : same (two copies)

49 Ibn al-Ḥājib Abū 'Amr Jamāl al-Dīn 'Uthmān b. 'Umar b. Abī Bakr's (d. 646/1249) work on Arabic syntax. Hulusi Kilıç, “el-Kâfiye”, DİA, v. XXIV, 153-154.

50 Since $L u b b$ and $L u b a \bar{b}$ are mentioned together, also the following article mentions the commentary on $L u b a \bar{b}$, these two, must be the works of Tãj al-Dīn Muhammad b. Muhammad b. Aḥmad al-Isfarāyinī's (d. 684/1285) Lubb al-albāb fì 'ilm al-i'rāb (Kashf, 1545) and al-Lubāb fí al-naḥw (Kashf, 1543) on Arabic syntax.

51 Quțb al-Dīn Muhammad b. Mas‘ūd b. Muhammad al-Sīrāfī al-Fālī’s (d. after 712/1312) commentary on al-Lubāb fi al-naḥw of Isfarāyinī (Kashf, 1544).

52 I could not locate any book entitled al-Khäfï in my research.

53 There are two well-known commentaries on Abū al-Hasan Najm al-Dīn Dabīrān 'Alī b. 'Umar al-Kātibī alQazvīnìs (d. 675/1277) work on logic: al-Risālat al-Shamsiyya fi al-qawāìd al-manțiqiyya before the list: (i) Quțb al-Dīn Muhammad b. Muhammad al-Rāzī al-Tahtānīs (d. 766/1365) Tahrīr qawāíd al-manțiqiyya fì sharh al-Shamsiyya by and (ii) Sa'd al-Dīn al-Taftāzānī’s Sharh al-Shamsiyya (Kashf, 1063).

54 Shams al-Dīn Muḥammad b. Ashraf al-Ḥusaynī al-Samarqandī's (d. 722/1322) Qisțās al-afkār fì taḥqīq al-asrār on logic (Kashf, 1326). Kātib Chalabī mentions the book as Qisțās al-mīzān.

55 Abū al-Ḥasan Burhān al-Dīn 'Alī b. Abī Bakr b. 'Abd al-Jalīl al-Farghānī al-Marghīnānī’s (d. 593/1197). work on Hanafi jurisprudence. Cengiz Kallek, "el-Hidâye”, DİA, v. XVII, 471-473.

56 I could not find any commentator of al-Hidāya called Sharaf al-Dīn al-Ṭawil in my research.

57 Jalāl al-Dīn al-Khwārizmī al-Kurlānī's (d. 767/1366) commentary on al-Hidāya: al-Kifāya fì sharḥ alHidāya (Kashf, 2034, footnote 1).

58 Many commentaries were written on Burhān al-Sharī‘a Maḥmūd b. Șadr al-Sharī‘a al-Awwal 'Ubayd Allāh al-Maḥbūbī al-Bukhārī's (d. 7-8/13-14c.) Wiqāyat al-riwāya fī masāỉ al-Hidāya (al-Wiqāya). When we consider the list's date, we can say that this commentary was authored by Ṣadr al-Sharī'a al-Thānī (Kashf, 2020 ff.; al-Habashī, Jāmi‘ al-Shurūh, III, 2149 ff.).

59 Abū Muhạmmad Qāsim b. 'Alī b. Muhammad al-Harīrīs (d. 516/1122) al-Maqāmāt (Kashf, 1787).

60 Abū Nașr Ismā'îl b. Hammād al-Jawharī’s (d. before 400/1009) lexicon known as al-Ṣihāḥ or Șihāh al-lugha. The book's full name is Tāj al-lugha wa șihāh al-'Arabiyya. Hulusi Kılıç, "Tâcü'l-luga”, DİA, v. XXXIX, 356-357.

61 Abū al-Faḍl Muhammad b. 'Umar b. Khālid al-Qarshī (d. after 702/1303), also known as Jamāl al-Qarshī, translated al-Jawharī's al-Ṣihạh into Persian. He completed his work in 681/1282 under the title al-Ṣurāḥ min al-Ṣihāh (Kashf, 1077). 
[36] Of the medicine books of India such as al-Banksin and al-Susrut ${ }^{62}$ and alBāhar, which was translated into Persian: fifteen copies

[37] Of al-Asbāb wa al-'alāmāt ${ }^{63}$ on medicine: three copies

[38] Of books on morphology (al-șarf): fourty-two copies

[39] Of al-Mașābīh ${ }^{64}$ and al-Jumal ${ }^{65}$ : thirty-five copies

[40] Of the prosody ('ilm al-'arūd): eight copies

[41] Of al-Miftāh. ${ }^{66}$ : eleven copies (including all chapters of the book)

[42] Of commentaries of poems (shurūh al-qașāid): sixteen copies

[43] Of Asmä' al-Muqaddima ${ }^{67}$ : nine copies

[44] Of Manāzil al-sā'irīn ${ }^{68}$ on 'ilm al-tașawwuf: five copies

[45] Of al-Muțawwal ${ }^{69}$ and al-Mukhtașar ${ }^{70}$ : eleven copies

[46] Of al-Mishkāt ${ }^{71}$ : two copies

62 This must be the translation of the six-chapter Susrutāsamhītā, one of the classical India's main medical texts. G. Jan Meulenbeld, A History of Indian Medical Literature, V. IA (Groningen: Forsten, 1999), $201 \mathrm{ff}$. I could not find any more information about the other books mentioned in this article.

63 This work on diseases and syndroms belongs to Najīb al-Dīn Abū Hāmid Muhammad b. 'Alī al-Samarqandī (d. 619/1222) (Kashf, 77).

64 Many works are titled al-Mișbāḥ. The most famous one is Abū al-Fatḥ Burhān al-Dīn Nāșir b. 'Abd al-Sayyid al-Muțarrizī al-Khwārizmì's (d. 610/1213) book on grammar, written to teach Arabic to his son Jamāl al-Dīn 'Alì (Kashf, 1708). Besides, the fact that this part of the list is mostly on books about grammar corroborates the idea that al-Muțarrizī authored al-Mișbāh.

65 Al-Jumal is a very popular title for books dealing with various scientific disciplines. But as the author mentions al-Mișbāh and al-Jumal in the same article, it is highly possible that al-Jumal focuses on grammar. The most famous al-Jumal grammar books are as follows: (i) Abū al-Qāsim 'Abd al-Raḥmān b. Ishạāq al-Nihāwandī al-Zajjājî̀s (d. 337/949) al-Jumal al-Kubrā and (ii) Abū Bakr 'Abd al-Qāhir b. 'Abd al-Raḥmān b. Muhammad al-Jurjānī’s (d. 471/1078) al-Jumal fi al-naḥw (Kashf, 602-603).

66 Miftāḥ al-'ulūm is Abū Ya'qūb Sirāj al-Dīn Yūsuf b. Abī Bakr al-Khwārizmī al-Sakkākīs (d. 626/1229) three-chapter book on the Arabic language. The third chapter (contains ma'ānī, bayān and badī) became especially popular, and many works were written on it (Kashf, 1762). Al-Tirmidhì indicates that he copied not only the third chapter, but the whole book by stating "including all chapters".

67 The Qismal-asmā' (chapter of nouns) of Zamakhsharī's Muqaddimat al-adab. One copy of the manuscript copied by al-Tirmidhì and completed four years after this list (Rajab 824/July 1421) is now in Fatih collection of Suleymaniye Library.

68 Abū Ismāīil 'Abd Allāh b. Muhammad b. 'Alī al-Anșārī al-Harawī's (also known as Khwāja 'Abd Allāh al-Harawī) work on tașawwuf. Erhan Yetik, “Menâzilü’s-sâirîn”, DİA, XXIX, 122-123.

69 A Talkhīs al-Miftāh was written by Abū al-Ma'ālī Jalāl al-Dīn al-Khațīb Muḥammad b. 'Abd al-Raḥmān al-Qazwīnī as an an epitome of the third chapter of Sakkākī's Miftāḥ al-'ulūm. Taftāzānī wrote two commentries on the Talkhīs. The long one is known as al-Muțawwal or al-Muțawwal fi al-ma'ānī wa al-bayān.

70 Sa‘d al-Dīn al-Taftāzānī shortened his long commentary (al-Muțawwal) on Talkhis al-Miftāḥ in 756/1355 as requested. This work is became famous as al-Mukhtașar, Mukhtașar al-Muțawwal, al-Sharḥ al-mukhtașar and al-Mukhtașar al-ma'ānī (Kashf, 474).

71 Many works are titled Mishkät, but the well-known and mosty circulated ones are: (i) al-Ghazzāli's Mishkāt al-anwār (Kashf, 1693) and (ii) Abū 'Abd Allāh Muhammad b. 'Abd Allāh al-Khațīb al-'Umarī al-Tabrīzì’s (d. 741/1340) work, Mishkāt al-Mașābīh on Mașābīh al-sunna of Farrā al-Baghawì (d. 516/1122). 
[47] Of al-Ḍaw' ${ }^{72}$ : five copies

[48] Of Sharh al-Shāfiya ${ }^{73}$ known as al-Järbardī: two copies

[49] Of al-Mutawassit ${ }^{74}$ : eight copies

[50] Of Sharh al-Raḍī $\bar{\imath}^{75}$ : one copy

[51] Of al-Ṭawāli ${ }^{76}$ on 'ilm al-kalām and of al-Mațāli ${ }^{77}$ : two copies

[52] Of Persian dīwāns such as the Dīwān ${ }^{78}$ of Hāfiz al-Shīrāzì and the Dìwān of Mawlānā Jalāl al-Dīn al-Rūmī: nine copies

[53] Of his al-Mathnawĩ: six copies

[54] Of 'Aț̣āariyyāt ${ }^{79}$, such as Ilāhīnāma, Asrārnāma, Mușībatnāma, Ushturnāma, and Manțiq al-țayr: five copies

Many works with this title are presented in the sources. However, the well-known and commonly circulated ones before the list were: (i) Tãj al-Dīn al-Isfarāyinī's Daw' al-Miṣbāḥ, a self-epitome of his commentary al-Miftāḥ that he had written on Muțarrizī's al-Miṣbāh (Kashf, 1708) and (ii) Abū al-'Alā Shams al-Dīn Maḥmūd b. Abī Bakr al-Bukhārī al-Kalābādhī’s (d. 700/1300) commentary Dậ'al-Sirāj, written on Abū Țāhir Sirāj al-Dīn Muhammad b. Muhammad al-Sajāwandī’s (d. after 596/1200) wellknown al-Farāit al al-sirājiyya on inheritance ('ilm al-farä’ị) (Kashf, 1249).

73 Abū al-Makārim Fakhr al-Dīn Ahmmad b. al-Hasan b. Yūsuf al-Charpardīs (d. 746/1346) commentary on Ibn al-Hājib’s al-Shāfiya (on Arabic morphology). (See Kashf, 1021; al-Habashī, Jāmi' al-Shurūḥ, II, 1070 ff.).

74 Rukn al-Dīn Ḥasan b. Sharafshāh al-Astarābādī (d. 715/1315 [?]) wrote three commentaries on Ibn al-Hājib's al-Kāfiya, all of which became famous: al-Kabìr, al-Mutawassiț, and al-Saghìr (Kashf, 1370).

75 Najm al-A'imma Raḍi al-Dīn Muhammad b. al-Ḥasan al-Astarābādī's (d. after 688/1289) commentary on Ibn al-Hājib's al-Kāfiya (Kashf, 1370).

76 Qāḍi al-Bayḍāwī's work on theology ('ilm al-kalām). The full name of the book is Ṭawāli' al-anwär min mațāli al-anzār. See Yusuf Şevki Yavuz, "Tavâliu'l-envâr”, DİA, v. XL, 180-181. The manuscript, which al-Tirmidhī copied on 9 Ramaḍān 803/23 April 1401, contains one of those Ṭawāli copies. (QumMar’ashī Library Ms 509).

77 Abū al-Thanā Shams al-Dīn Maḥmūd b. 'Abd al-Raḥmān b. Aḥmad al-Ișfahānī's (d. 749/1349) commentary on al-Bayḍāwī's Ṭawāli' al-anwār. He named his commentary Mațāli' al-anz̄âr.

78 One of the greatest Persian poets, Khwāja Shams al-Dīn Muhammad al-Shīrāzī (d. 792/1390). See Tahsin Yazıcı, "Hâfız-1 Şîrâzî", DİA, v. XV, 103-106.

79 'Ațtāriyyāt must be the common name of the mathnawīs of Abū Hāmid Farīd al-Dīn Muhammad b. Abī Bakr Ibrāhīm al-Nīsābūrī (d. 618/1221), because all of the mentioned works belong to Farīd al-Dīn al-'Attār. See M. Nazif Şahinoğlu, "Attâr, Ferîdüddîn”, DİA, v. IV, 95-98. 
Appendix 3. The colophon of al-Tirmidhī at the end of al-Rumi's Mathnawī

Süleymaniye Library, Fatih 2810, f. 299a

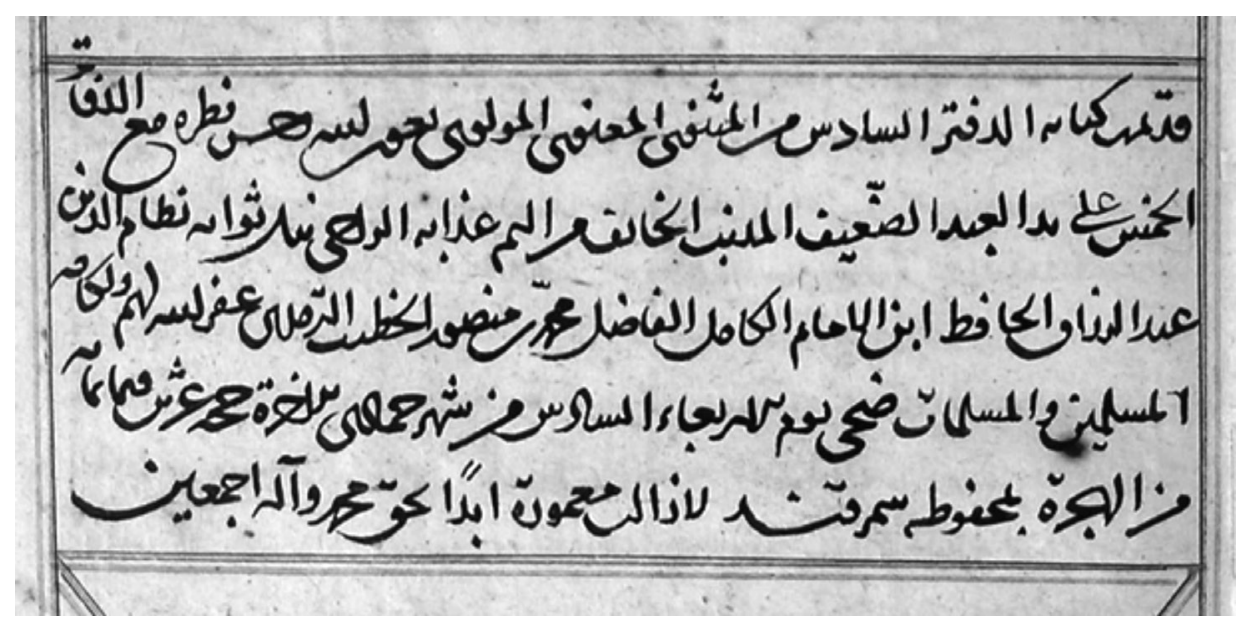

قد تمّت كتابة الدفتر السادس من المثنوي المعنوي المولوي بعون الله وحسن نظره مع الدفاتر الخمس على يد العبد الضعيف المذنب الخائف من أليم عذابه، الراجي نيل ثو ابه، نظام الدين عبد الرزّاق الحافظ ابن

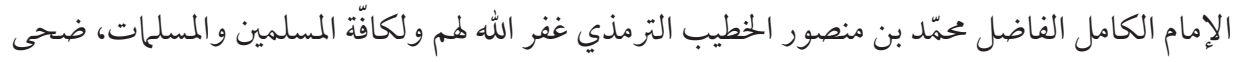
يوم الأربعاء السادس من شهر جمادى الآخرة حجّة عشرين وثمانمائة من الهجرة بمحفوظة سمرقند لا زالت معمورة أبدًا بحقّ محمّد وآله أجمعين منين 


\section{Appendix 4. The frontispiece of the Mathnawī, which al-Tirmidhì copied}

Süleymaniye Library, Fatih 2810, f. 1a- "frontispiece"

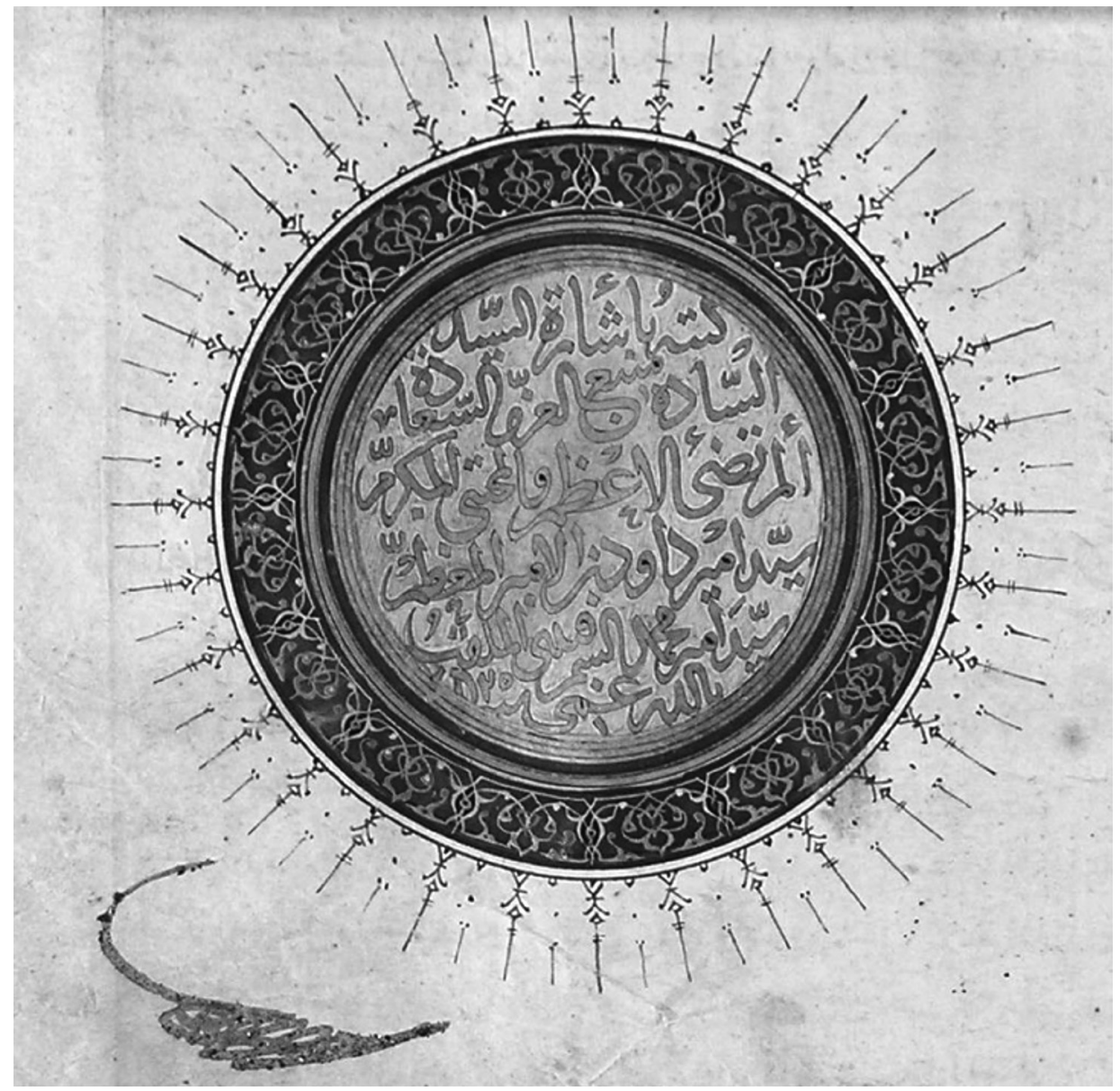

كتبه بإشارة السيّد السادة، منبع العزّ والسعادة، المرتضى الأعظم والمجتبى المكرّم، سيّد أمير داود بن

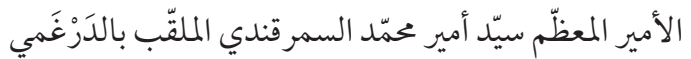


Appendix 5. The list of the books that al-Tirmidhi copied

Süleymaniye Library, Fatih 2810, f. 299b

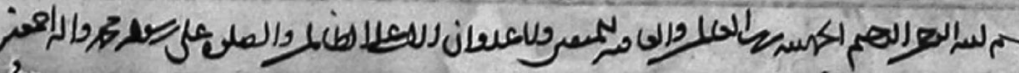

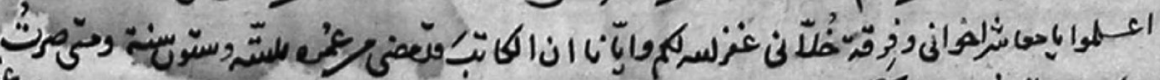

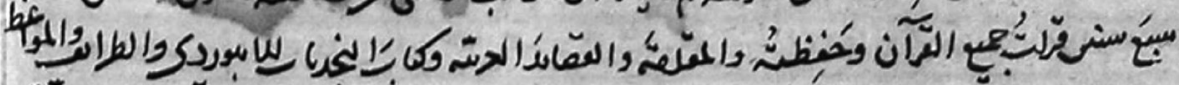

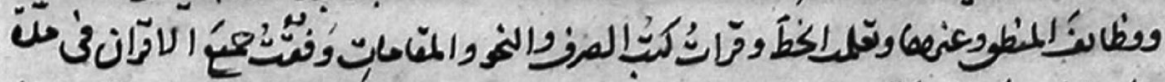

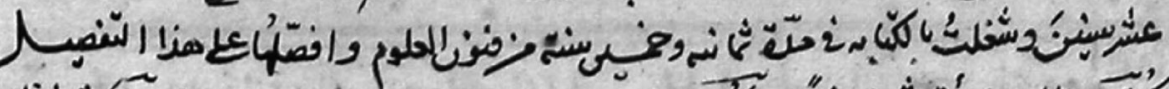

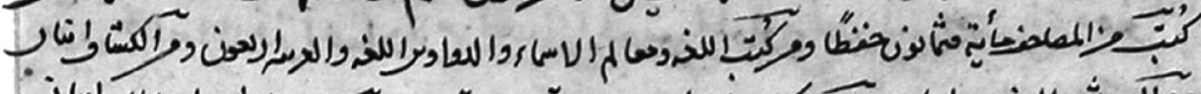

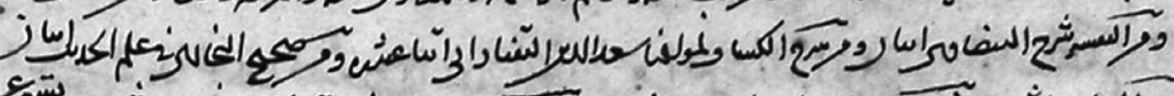

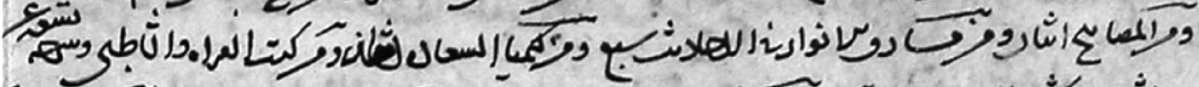

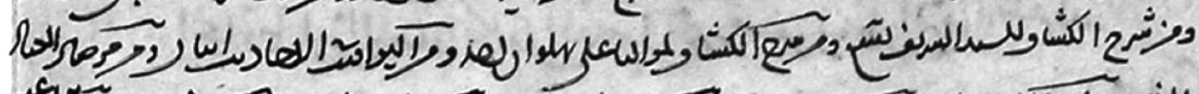
\&L

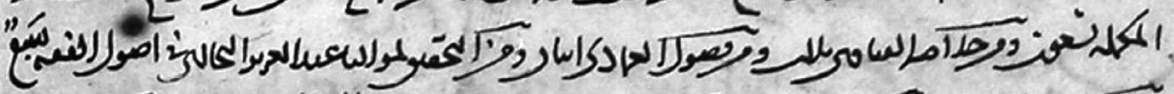

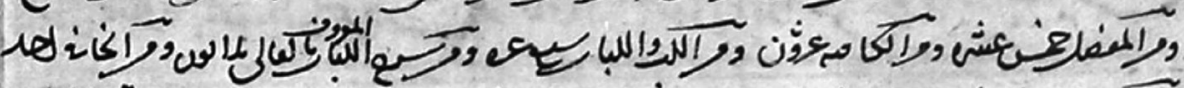

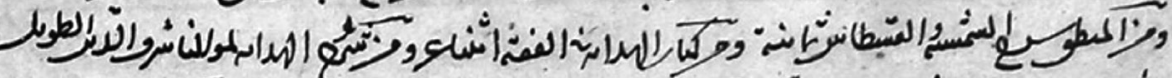

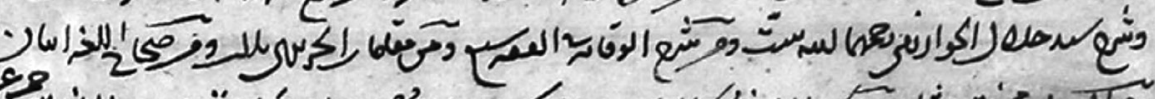

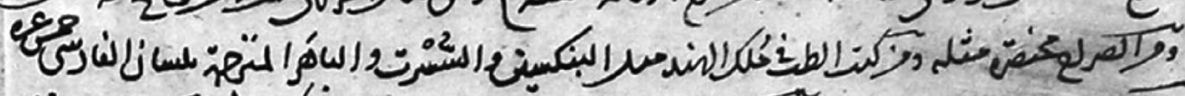

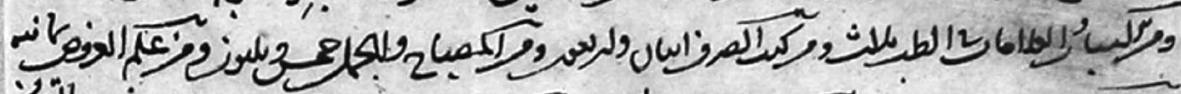
goille

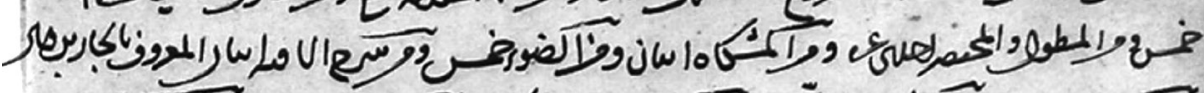

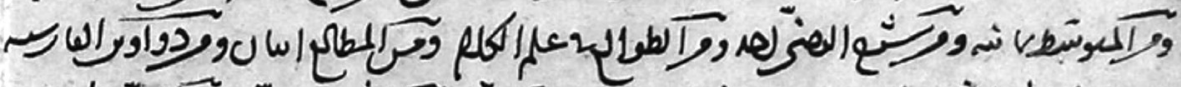

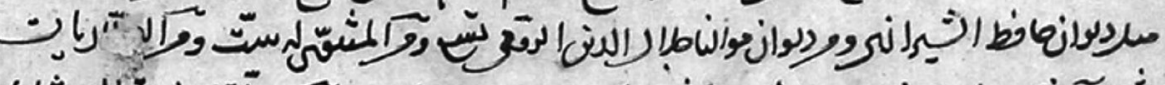

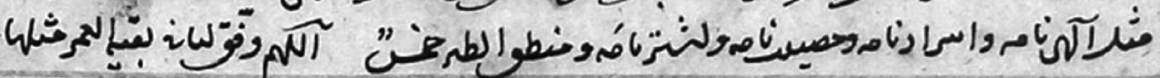

